\title{
Continuous sodium valproate or phenobarbitone in the prevention of 'simple' febrile convulsions
}

\author{
Comparison by a double-blind trial
}

EUGENIA NGWANE AND BRIAN BOWER

Department of Paediatrics, Radcliffe Infirmary, Oxford

SUMMARY Of the 265 children aged between 6 and 18 months admitted to hospital in a 26-month period each with his first febrile convulsion, there were 64 who satisfied our criteria for a simple febrile convulsion. Of these, 43 (random) were entered into a double-blind trial of continuous sodium valproate versus phenobarbitone, and 21 were untreated. The dosage was phenobarbitone $3-6 \mathrm{mg} / \mathrm{kg}$ per day; sodium valproate $30-60 \mathrm{mg} / \mathrm{kg}$ per day. 39 completed treatment ( 21 phenobarbitone, 18 sodium valproate), 2 in each group being withdrawn because of unacceptable side effects. Close supervision and random serum drug estimations showed compliance to be good.

After a mean treatment period of 12 months (mean age 25 months) there had been one recurrence in the sodium valproate group compared with 7 in the untreated group $(P<0.05)$, and 4 recurrences in the phenobarbitone group. The difference between treatment and no treatment was significant $(\mathrm{P}<0.05)$.

These results suggest that in simple febrile convulsions occurring between 6 and 18 months of age sodium valproate is as effective as phenobarbitone in preventing recurrence and that either treatmen. is better than none.

The prevention of febrile convulsions has become particularly important since it has been shown that prolonged convulsions may cause temporal lobe epilepsy. ${ }^{1-2}$ The risk that a convulsion will be prolonged increases with each succeeding convulsion. ${ }^{3}$ There is therefore good reason to try to prevent further convulsions once a child has identified himself as being at risk by having his first febrile convulsion.

Prophylactic intermittent phenobarbitone is ineffective since it takes up to 72 hours to achieve an adequate blood level even at double the ordinary dose. $^{4-6}$ Continuous phenytoin is also ineffective. ${ }^{7}$ By contrast continuous phenobarbitone has been found to have some prophylactic effect, ${ }^{8-10}$ although in one trial this did not reach statistical significance. ${ }^{11}$ As sodium valproate (Epilim) has been shown to be a safe and effective anticonvulsant in tonic-clonic seizures, ${ }^{12-15}$ we decided to test its effectiveness in preventing the recurrence of febrile convulsions.

Department of Paediatrics, Radcliffe Infirmary, Oxford

EUGENIA NGWANE, research assistant

BRIAN BOWER, consultant paediatrician

\section{Patients and methods}

Between April 1976 and June 1978, 265 children (180 boys and 85 girls) aged between 6 and 18 months were admitted to the Radcliffe Infirmary or the Churchill Hospital, Oxford, with their first febrile convulsions. Of these, 64 had each had a simple febrile convulsion which, for the purposes of this study, fulfilled the following criteria: (1) It was a generalised tonic-clonic convulsion which was not lateralised or followed by lateralised postictal paralysis. (2) Its duration was less than 30 minutes. (3) The patient had a normal perinatal and postnatal history and there was no history of neurological disease. (4) There was no evidence of current intracranial disease.

43 of the 64 children were entered into a doubleblind trial of continuous sodium valproate against continuous phenobarbitone. Informed parental consent was obtained. The remaining 21 of these 64 children were not entered into the trial either because of parental refusal or because they were admitted on a 'take' day of a consultant who did not wish to participate in the trial. These 21 children form the untreated group. 
For technical reasons it was not possible to provide phenobarbitone tablets identical in taste and appearance with sodium valproate or to provide identical syrups. However it was possible to provide placebo tablets and syrup which were identical with each active preparation in taste and appearance. Each patient was therefore given medication both in tablet and syrup form, one of which was placebothat is either phenobarbitone tablets and placebo syrup, or placebo tablets and sodium valproate syrup. Dosage was twice daily. Allocation was random and double-blind, the code being kept by the hospital pharmacist. The dose of the anticonvulsant was determined according to the child's body weight at entry into the trial. Children weighing $5-10 \mathrm{~kg}$ received phenobarbitone in a dose of $30 \mathrm{mg}$ or sodium valproate in a dose of $300 \mathrm{mg}$, and those weighing $>10-15 \mathrm{~kg}$ received phenobarbitone $45 \mathrm{mg}$ or sodium valproate $400 \mathrm{mg}$ (Table 1).

The patients were followed by one of us (E N) for an average period of 12 months.

Patients were reviewed 2 weeks after discharge, then after a further 2 months, and thereafter at 4-monthly intervals unless otherwise indicated. On discharge from hospital the parents were given instruction about antipyretic measures to be taken in the event of a febrile illness. ${ }^{16}$

\section{Results}

39 children (21 in the phenobarbitone group and 18 in the sodium valproate group) remained in the trial from the time of entry to the time that the code was broken at the end of the period of observation. Four children, 2 in each treatment group, developed such severe side effects that the code was broken and treatment stopped. The side effects consisted of pronounced hyperactivity and night wakefulness in the phenobarbitone group and persistent diarrhoea in the sodium valproate-treated children.

Blood level estimations both of scdium valproate and phenobarbitone were done on 28 of the 39 children in the trial. Blood samples were taken 2-4 hours after the morning dose. A total of 35 estimations were done, 16 in the phenobarbitone group and 19 in the sodium valproate group. These were done at random intervals and the parents had no warning

Table 1 Anticonvulsants given to the two groups according to body weight

\begin{tabular}{lll}
\hline & \multicolumn{2}{l}{ Body weight at entry into trial } \\
\cline { 2 - 3 } & $5-10 \mathrm{~kg}$ & $>10-15 \mathrm{~kg}$ \\
\hline Phenobarbitone & $30 \mathrm{mg}$ daily & $45 \mathrm{mg}$ daily \\
& $(3-6 \mathrm{mg} / \mathrm{kg}$ per day $)$ & $(3-4 \mathrm{mg} / \mathrm{kg}$ per day $)$ \\
Sodium valproate & $300 \mathrm{mg}$ daily & $400 \mathrm{mg}$ daily \\
& $(30-60 \mathrm{mg} / \mathrm{kg}$ per day $)$ & $(26-40 \mathrm{mg} / \mathrm{kg}$ per day $)$ \\
\hline
\end{tabular}

that a blood test would be done at the next clinic. Of the 19 estimations in the sodium valproate group, only one was below the therapeutic range $(0 \cdot 26$ $\mathrm{mmol} / 1 ; 4 \cdot 3 \mathrm{mg} / 100 \mathrm{ml}$ ). In the phenobarbitone group, 4 of the 16 estimations were below the therapeutic range: $25 \mu \mathrm{mol} / 1(0.58 \mathrm{mg} / 100 \mathrm{ml})$; $30 \mu \mathrm{mol} / 1 \quad(0.70 \mathrm{mg} / 100 \mathrm{ml}) ; 38 \mu \mathrm{mol} / 1 \quad(0 \cdot 88$ $\mathrm{mg} / 100 \mathrm{ml}) ; 37 \mu \mathrm{mol} / 1(0.86 \mathrm{mg} / 100 \mathrm{ml})$. The therapeutic range was taken as $0.3-0.7 \mathrm{mmol} / \mathrm{l}$ $(4.98-11.62 \mathrm{mg} / 100 \mathrm{ml})$ for sodium valproate and $40-100 \mu \mathrm{mol} / 1(0.93-2.32 \mathrm{mg} / 100 \mathrm{ml})$ for phenobarbitone.

The number of febrile episodes $\left(\mathrm{T}^{\circ}>38^{\circ} \mathrm{C}\right)$ was similar in the two treated groups. In the phenobarbitone group there was an average of 4 febrile episodes (range 2-8) and in the sodium valproate group an average of 3 (range 2-7), during the period of observation. There were 8 readmissions to hospital with febrile illnesses but no recurrence of febrile convulsions in any of these.

Are these three groups comparable? The children in all three groups were comparable for age at beginning and end of the trial and for length of period of observation (Table 2).

The number of recurrences during the period of observation is shown in Table 3.

Only one patient in the sodium valproate group had a recurrence. In the phenobarbitone group there were 4 . By contrast, of the 21 patients in the untreated group 7 had further fits during the period of observation.

Table 2 Age and follow-up period distribution

\begin{tabular}{|c|c|c|c|}
\hline & $\begin{array}{l}\text { Sodium } \\
\text { valproate } \\
(n=20, \\
10 \mathrm{M} \text { and } 10 \mathrm{~F})\end{array}$ & $\begin{array}{l}\text { Phenobarbitone } \\
(n=23 \text {, } \\
13 \mathrm{M} \text { and } 10 \mathrm{~F})\end{array}$ & $\begin{array}{l}\text { Untreated } \\
(n=21 \text {, } \\
14 M \text { and } 7 F)\end{array}$ \\
\hline \multicolumn{4}{|l|}{ Follow-up (months) } \\
\hline \multicolumn{4}{|l|}{ Maximum with- } \\
\hline $\begin{array}{l}\text { out recurrence } \\
\text { Mean }\end{array}$ & 20 & 27 & $\begin{array}{l}24 \\
13\end{array}$ \\
\hline Median & 15 & $12 \frac{1}{2}$ & 15 \\
\hline \multicolumn{4}{|c|}{ Age at entry (months) } \\
\hline $\begin{array}{l}\text { Mean } \\
\text { Median }\end{array}$ & $\begin{array}{l}12 \frac{1}{2} \\
13\end{array}$ & $\begin{array}{l}12 \frac{1}{2} \\
14\end{array}$ & $\begin{array}{l}12 \frac{1}{2} \\
13\end{array}$ \\
\hline Mean age at end & of & & \\
\hline trial (months) & 25 & 25 & 28 \\
\hline
\end{tabular}

Table 3 Recurrence rate and side effects in the three groups

\begin{tabular}{lccl}
\hline & $\begin{array}{l}\text { Sodium } \\
\text { valproate } \\
(n=20)\end{array}$ & $\begin{array}{l}\text { Phenobarbitone } \\
(n=23)\end{array}$ & $\begin{array}{l}\text { Untreated } \\
(n=21)\end{array}$ \\
\hline $\begin{array}{l}\text { Side effects, code } \\
\text { broken }\end{array}$ & 2 & 2 & - \\
$\begin{array}{l}\text { No. remaining in trial } \\
\text { Recurrences }\end{array}$ & 18 & 21 & 21 \\
\hline
\end{tabular}


The difference between the sodium valproate and the untreated groups was significant $\left(\chi^{2}=3 \cdot 8\right.$ $\mathbf{P}<0.05$ ); as was the difference between all treated subjects (sodium valproate and phenobarbitone groups combined $)$ and the untreated group $\left(\chi^{2}=4 \cdot 3\right.$ $\mathbf{P}<0.05)$. The difference between the sodium valproate and the phenobarbitone group was not significant.

\section{Discussion}

Two reasons account for the small numbers in this trial. Firstly, the strictness of our definition. Previous reports show considerable confusion about the definition of febrile convulsions which differ greatly in severity, aetiology, and precipitating factors, making controlled trials difficult. ${ }^{17}$ We decided to adhere to a strict definition even though this reduced the numbers. Secondly, the restriction of our cases to those below 18 months. There is a greater risk of further convulsions in children whose first fit takes place before they are 18 months. ${ }^{3}$ It therefore seemed justifiable to use sodium valproate in such children although little is known about its long-term effects in the immature brain. We felt that its use in the low risk (that is, older) group was unjustifiable.

The aim of the trial was to discover whether sodium valproate was as effective as phenobarbitone in the prophylaxis of febrile convulsions. This has been shown to be the case in the age of greatest risk.

Is sodium valproate preferable to phenobarbitone? In this study sodium valproate was more effective although the difference was not significant. Contrary to our expectations, the incidence of side effects in the two groups was similar. Five of 23 phenobarbitone-treated children developed side effects, and in 2 these were so severe that both children were withdrawn from the trial. In all cases the parents volunteered the information and the side effects began within 72 hours of starting treatment.

In the sodium valproate group 4 children developed side effects, 2 of whom were withdrawn from the trial. The most common side effect was diarrhoea. This invariably resolved even when treatment was maintained. In one instance, treatment was stopped due to intolerable diarrhoea and the patient was treated with phenobarbitone, this was later stopped due to excessive hyperactivity and the child put back on sodium valproate. There was no recurrence of diarrhoea.

Although the untreated group appears to be comparable with the two treated groups, it was not designed as a control group. Nevertheless comparison of the incidence of recurrence $(33 \%$ in the untreated group and $5.5 \%$ in the sodium valproate group) suggests that continuous prophylactic medication reduces the risk of recurrence.

Moreover, 6 out of the 7 children who had recurrences in the untreated group each had at least one subsequent seizure which lasted 25 minutes or longer. Such prolonged seizures carry a substantial risk of the development of anoxic brain damage and chronic temporal lobe epilepsy. Simple febrile convulsions, as defined by us, are therefore not necessarily benign and in our view prophylactic treatment is justifiable.

From this trial we conclude: (1) That sodium valproate is at least as effective as phenobarbitone in the prophylaxis of febrile convulsions. (2) That there are side effects which although different are equally likely. (3) That treatment with either sodium valproate or phenobarbitone prcduced a significant reduction in the incidence of further convulsions.

We recommend that any child below age 18 months who presents with febrile convulsions should be treated with either sodium valproate or phenobarbitone for at least 12 months from the time of his first febrile convulsion.

We thank the consultant paediatricians at the Radcliffe Infirmary and Churchill Hospital for allowing us to study children under their care, Dr B Winsley and the staff of the pharmacy for their willing help, Dr J Mann for advice on the design of the trial and evaluation of results, Miss J Bradley for secretarial help, Reckitt and Colman Limited for the supplies of sodium valproate and placebo, and the parents of our patients for their understanding and co-operation.

\section{References}

1 Taylor D C, Ounsted C. Biological mechanisms influencing the outcome of seizures in response to fever. Epilepsia 1971; 12: 33-45.

${ }^{2}$ Falconer M A, Serafetinides E A, Corsellis J A N. Etiology and pathogenesis of temporal lobe epilepsy. Arch Neurol 1964; 10: 233-48.

${ }^{3}$ Lennox-Buchthal M. Febrile convulsions. A reappraisal. Electroencephalogr Clin Neurophysiol 1973; Supplement 32.

4 Svensmark O, Buchthal F. Dosage of phenytoin and phenobarbital in children. Dan Med Bull 1963; 10: 234-5.

5 Svensmark O, Buchthal F. Diphenylhydantoin and phenobarbital. Serum levels in children. Am J Dis Child $1964 ; 108$ : 82-7.

6 Millichap J G, Aledort L M, Madsen J A. A critical evaluation of therapy of febrile seizures. J Pediatr 1960; 56: 364-8.

7 Melchior J C, Buchthal F, Lennox-Buchthal M. The ineffectiveness of diphenylhydantoin in preventing febrile convulsions in the age of greatest risk, under three years. Epilepsia 1971; 12: 55-62. 
8 Faerø O, Kastrup $\mathrm{K}$ W, Nielsen E L, Melchior J C, Thorn I. Successful prophylaxis of febrile convulsions with phenobarbital. Epilepsia 1972; 13: 279-85.

9 Wolf S M, Carr A, Davis D C, et al. The value of phenobarbital in the child who has had a single febrile seizure: a controlled prospective study. Pediatrics 1977 ; 59: 378-85.

10 Wallace S J. Continuous prophylactic anticonvulsants in selected children with febrile convulsions. Acta Neurol Scand (Suppl) 1975; Supplement 60, 62-6.

11 Heckmatt J Z, Houston A B, Clow D J, et al. Failure of phenobarbitone to prevent febrile convulsions. $\mathrm{Br} \mathrm{Med} J$ 1976; i: 559-61.

12 Jeavons P M, Clark J E. Sodium valproate in treatment of epilepsy. $\mathrm{Br}$ Med $J 1974$; ii : 584-6.

13 Jeavons P M, Clark J E, Maheshwari M C. Treatment of generalised epilepsies of childhood and adolescence with sodium valproate (Epilim). Dev Med Child Neurol 1977; 19: 9-25.
14 Barnes S E, Bower B D. Sodium valproate in the treatment of intractable childhood epilepsy. Dev Med Child Neurol 1975 ; 17 : 175-81.

15 Haigh D, Forsythe W I. The treatment of childhood epilepsy with sodium valproate. Dev Med Child Neurol 1975; 17: 743-8.

16 Bower B D. The treatment of epilepsy in children. $\mathrm{Br} J$ Hosp Med 1978; 19: 8-19.

17 Stephenson J B P. Two types of febrile seizure: anoxic (syncopal) and epileptic mechanisms differentiated by oculocardiac reflex. $\mathrm{Br} \mathrm{Med} J$ 1978; ii : 726-8.

Correspondence to Dr Eugenia Ngwane, Department of Paediatrics, John Radcliffe Hospital, Headington, Oxford OX3 9DU.

Received 24 April 1979 